\title{
Bioaccumulation, alterations of metallothionein, and antioxidant enzymes in the mullet Mugil cephalus exposed to hexavalent chromium
}

\author{
Eun Young Min ${ }^{1}$, Tae Young Ahn ${ }^{2}$ and Ju-Chan Kang ${ }^{2^{*}}$
}

\begin{abstract}
A laboratory experiment was conducted to determine hexavalent chromium $\left(\mathrm{Cr}^{6+}\right)$ accumulation in the mullet and investigate $\mathrm{Cr}^{6+}$ toxicity using a panel of biomarkers including metallothioneins (MTs), glutathione (GSH), glutathione S-transferase (GST), and superoxide dismutases (SODs) for 4 weeks. $\mathrm{Cr}^{6+}$ bioaccumulation in all tissues, except muscle, was consistently time- and dose-dependent. The accumulation of $\mathrm{Cr}^{6+}$ for 4 -week exposures was in the following order: kidney $\approx$ liver $>$ intestine $\approx$ gill $>$ spleen $>$ muscle. Compared with the control, $\mathrm{Cr}^{6+}$ bioaccumulation was increased in $\geq 200 \mu \mathrm{g} \mathrm{L}^{-1}$ groups $(P<0.05)$. An independent relation was observed between accumulation factors (AFs) and exposure concentration. But AFs increased with exposure time. In the liver and gill, GST and SOD differed from the control at a high $\mathrm{Cr}^{6+}$ concentration at 2 and 4 weeks $(P<0.05)$. This study indicated that the gills were as sensitive as the liver to $\mathrm{Cr}^{6+}$ toxicity. However, the latter appeared to influence largely on the organism's adaptive response to $\mathrm{Cr}^{6+}$, since $\mathrm{Cr}^{6+}$ may elevate GSH and MT levels by enhancing the hepatic uptake of metal in the mullet.
\end{abstract}

Keywords: Hexavalent chromium, Mullet, Bioaccumulation, Metallothionein, Antioxidant enzymes

\section{Background}

Heavy metals are considered major anthropogenic contaminants in marine environments, as they pose a serious threat to marine organisms due to their toxicity, persistence, and bioaccumulation tendencies (DeForest et al. 2007). Chromium is an essential microelement in insulin-related functions, but it is also a toxic element. A typical feature of chromium in the environment is that it does not disappear but merely changes its form and valence. Demirak et al. (2006) reported that the gills are the major site for $\mathrm{Cr}$ accumulation due to their close relationship with the external environment. Hexavalent chromium $\left(\mathrm{Cr}^{6+}\right)$ induces histological alterations in fish, including hyperplasia of the gill epithelium and fusion of the secondary gill lamella. However, the liver plays a major role in the detoxification of metals through the induction

\footnotetext{
* Correspondence: jckang@pknu.ac.kr

${ }^{2}$ Department of Aquatic Life Medicine, Pukyong National University, Busan 608-737, South Korea

Full list of author information is available at the end of the article
}

of metal-binding proteins such as metallothionein (MT) (Linde et al. 2005). MT, a metal-binding protein, is a low molecular weight cysteine-rich protein that not only plays an important role in the transport and storage of essential metals but also provides protection against the toxic effect of metals (Lange et al. 2002). In aquatic species, exposure to metal increases the MT level (Lange et al. 2002). The MT induction in fish is known to be high in tissues directly involved in metal uptake, storage, and excretion, such as the gill, liver, kidney, intestine, and muscle (Amiard et al. 2006). The toxic effects of $\mathrm{Cr}$ are widely believed to be associated with the stimulation of free radical processes as well as the formation of highly reactive intermediates of $\mathrm{Cr}^{6+}$ reduction (Lushchak et al. 2008). Reactive oxygen species (ROS) which are generated during $\mathrm{Cr}^{6+}$ degradation exert oxidative stress in cells (Wang et al. 2004). As a result, the biological system induces antioxidants such as superoxide dismutase (SOD), catalase, and glutathione (GSH)-related enzymes to combat the increased levels of ROS. Antioxidant enzymes 
serve as excellent biomarkers to study oxidative stress in aquatic organisms. Roberts and Oris (2004) investigated a series of biomarkers in rainbow trout, Oncorhynchus mykiss, in response to $\mathrm{Cr}$ toxicity. Arillo and Melodia (1998) also pointed out that $\mathrm{Cr}^{6+}$ induces alterations in the oxidative function of mitochondria in trout. Furthermore, the intracellular fate of both essential and non-essential metal ions strongly depends on thiolcontaining molecules, particularly GSH and MT (Schlenk and Rice 1998). Therefore, the objectives of this study were (a) to investigate $\mathrm{Cr}^{6+}$ accumulation in tissues of the mullet Mugil cephalus, after waterborne exposure and (b) to investigate the effects of exposure to $\mathrm{Cr}^{6+}$ on MT and GSH levels including glutathione $S$-transferase (GST) and SOD activities in the liver and gills to elucidate the cause and effect relationship between metals and antioxidant responses.

\section{Methods}

Experimental animals and waterborne exposure test

Mullet $M$. cephalus (weight, $48.25 \pm 8.36$ g; length, $17.23 \pm 0.85 \mathrm{~cm}$ ) were collected from an aquafarm in Ha-Dong, South Korea, and were acclimatized to laboratory conditions for 4 weeks before experimentation. The water quality parameters measured for the bioassay were as follows: $\mathrm{pH}, 8.10 \pm 0.2$; salinity, $33.50 \pm 0.6 \%$; DO, 7.14 $\pm 0.3 \mathrm{mg} \mathrm{L}^{-1}$; and chromium, $\leq 0.1 \mu \mathrm{g} \mathrm{L}^{-1}$. All experiments were conducted in a seawater temperature of $20 \pm 0.5{ }^{\circ} \mathrm{C}$ under a 12-h light/12-h dark cycle. Experimental fish were exposed to waterborne treatments of $0,25,50,100,200$, and $400 \mu \mathrm{g} \mathrm{L}^{-1} \mathrm{Cr}^{6+}$ concentrations for 4 weeks. Potassium dichromate (Sigma-Aldrich, Inc., USA) was used as the test compound, and the culture water was renewed every 2 days. Fish were anesthetized using benzocaine, and the liver, gill, kidney, spleen, and muscle were sampled and kept at $-80{ }^{\circ} \mathrm{C}$ until analysis after exposures of 2 and 4 weeks.

\section{Analysis of $\mathrm{Cr}^{6+}$ accumulation in tissues}

Each tissue was lyophilized to constant weight and then digested using the wet digestion method. Lyophilized organs were dissolved in $\mathrm{HNO}_{3}$ and re-dried by heating to $120{ }^{\circ} \mathrm{C}$. Final samples were dissolved in $2 \%$ $\mathrm{HNO}_{3}$ and used for analysis after filtration (Advantec MFS, Inc., $0.2-\mu \mathrm{m}$ filter). The concentration of total chromium in tissues was measured using an ICP-MS (Elan, PerkinElmer, Inc., USA) equipped with an automatic sampler using argon gas. The accumulation factor (AF) is measured by the following formula: $\quad A F=[\mathrm{Me}]_{\mathrm{fw}, \exp }-[\mathrm{Me}]_{\mathrm{fw}, \text { control }} /[\mathrm{Me}]_{\mathrm{water}}$, where $[\mathrm{Me}]_{\mathrm{fw}, \exp },[\mathrm{Me}]_{\mathrm{fw}, \text { control}}$, and $[\mathrm{Me}]_{\mathrm{water}}$ are the metal concentrations in the experimental group, control group, and water, respectively, measured in micrograms per gram (Holwerda 1991).

\section{Analysis of MT and antioxidant enzyme activity}

The liver and gill tissues used to determine enzyme activity were rinsed in $0.1 \mathrm{M} \mathrm{KCl}(\mathrm{pH} \mathrm{7.4)}$ ) and homogenized (099CK4424, Glas-Col, Germany) in 0.1 M PBS $(\mathrm{pH}$ 7.4). The homogenate was centrifuged at $10,000 \times g$ for $60 \mathrm{~min}\left(+4{ }^{\circ} \mathrm{C}\right)$, and the supernatant was used for GST and SOD assays. To determine MT and GSH, tissues were homogenized in $20 \mathrm{mM}$ Tris buffer $(\mathrm{pH} 7.8)$ containing $0.25 \mathrm{M}$ sucrose. The homogenate was centrifuged at $10,000 \times g$ for $30 \mathrm{~min}\left(+4^{\circ} \mathrm{C}\right)$, and the supernatant was used for assays. The supernatant was stored at $-75^{\circ} \mathrm{C}$ prior to analysis. Protein concentrations were determined using the method of Bradford (1976), with bovine serum albumin as a standard. MT was measured at $412 \mathrm{~nm}$ following the method of Viarengo and Nott (1993) using $0.25 \mathrm{M} \mathrm{NaCl}, 1 \mathrm{~N} \mathrm{HCl}$ containing $4 \mathrm{mM}$ EDTA, and 0.2 $\mathrm{M}$ sodium phosphate solution containing $0.43 \mathrm{mM}$ 5,5-dithiobis-2-nitrobenzoic acid (DTNB). GSH was measured at $412 \mathrm{~nm}$ following the method of Srivastava and Beutler (1970) using a precipitation solution containing metaphosphoric acid, disodium ethylenediamine tetraacetic acid ( $\mathrm{Na}_{2}$ EDTA), $0.3 \mathrm{M} \mathrm{Na} \mathrm{NPO}_{4}$ solution, and $0.5 \mathrm{mM}$ DTNB. The GSH level was evaluated and determined using the reduced glutathione standard curve. The SOD activity was measured at $450 \mathrm{~nm}$ using an SOD Assay Kit-WST (Dojindo Co., Japan) to determine the $50 \%$ inhibitor rate of the reduction of 2-(4-lodophenyl)-3-(4-nitrophenyl)-5-(2,4-disulfophenyl)- $2 H$-tetrazolium, monosodium salt (WST-1). The SOD activity at the $50 \%$ inhibitor rate was expressed as units per milligram protein. GST activity was measured using $0.2 \mathrm{M}$ potassium phosphate ( $\mathrm{pH}$ 6.5), $10 \mathrm{mM}$ GSH, and $20 \mu \mathrm{L}$ of $10 \mathrm{mM}$ CDNB. This enzyme assay was according to the methods of Habig et al. (1974) with minor modifications (Anosike et al. 1991). GST activity was determined by an absorbance increase at $340 \mathrm{~nm}$ after $5 \mathrm{~min}$ and was expressed as nanomoles per minute per milligram protein. For statistical analysis, a one-way analysis of variance (ANOVA) was used followed by Duncan's multiple range tests using SPSS statistical software (SPSS Inc., Chicago, IL, USA). Differences were considered statistically significant when $P<0.05$.

\section{Results and discussion}

\section{$\mathrm{Cr}^{6+}$ accumulation in the organs}

$\mathrm{Cr}^{6+}$ accumulation in the organs of the mullet depending on the exposure time and exposure dose are shown in Fig. 1. As evidenced, the $\mathrm{Cr}^{6+}$ accumulation resulted in a net increase of the total $\mathrm{Cr}^{6+}$ content in all organs except the muscle with respect to the control. At $400 \mu \mathrm{g} \mathrm{L}{ }^{-1}$, the liver, kidneys, intestine, and gill showed similar $\mathrm{Cr}^{6+}$ contents; however, these four organs statistically differed from the control. The accumulation patterns of $\mathrm{Cr}^{6+}$ after 4-week exposure occurred in the following order: kidney 

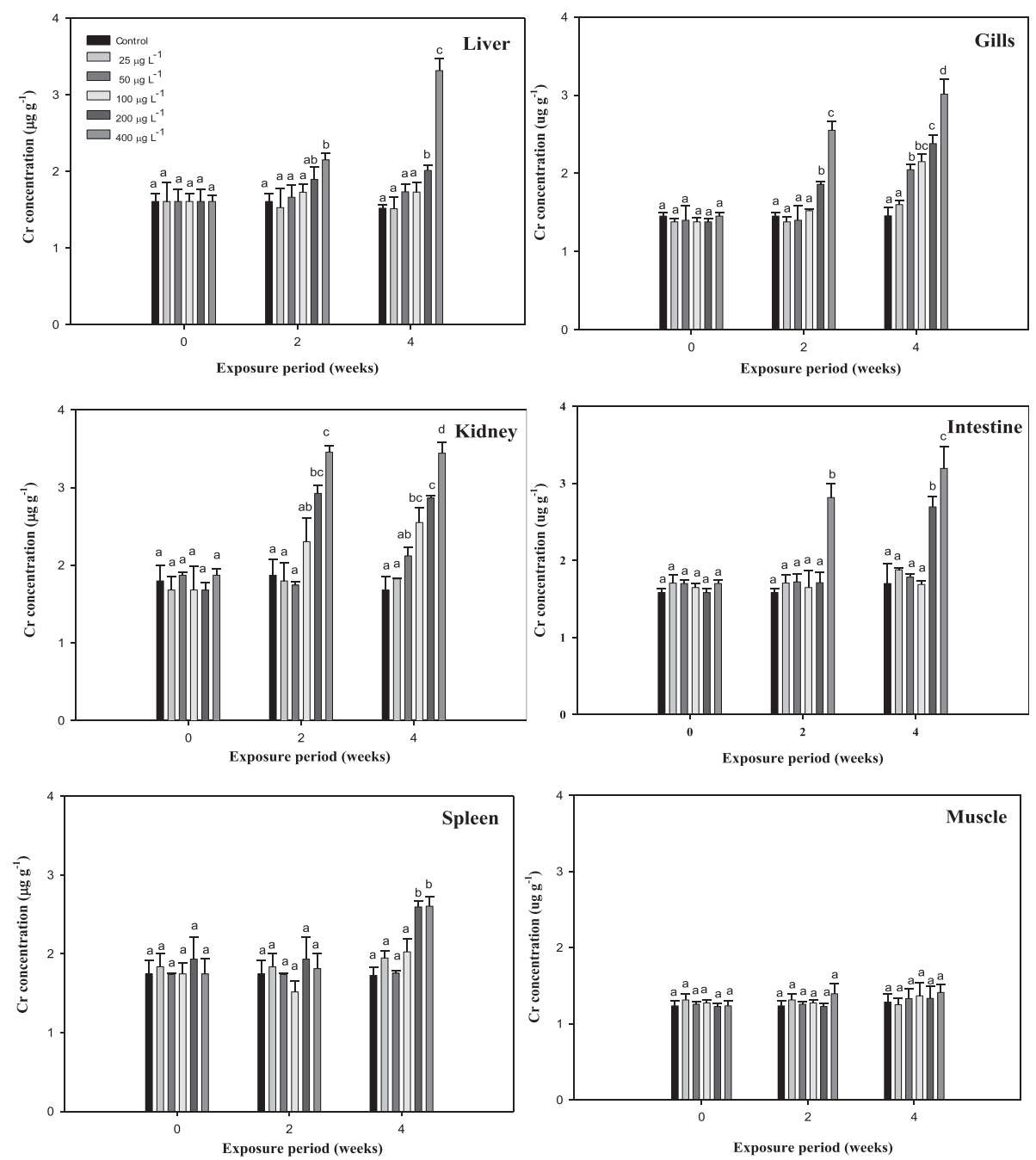

Fig. 1 Accumulation of hexavalent chromium $\left(\mathrm{Cr}^{6+}\right)$ in the selected organ tissues of mullet; $\mathrm{M}$. cephalus exposed to the different $\mathrm{Cr}^{6+}$ concentrations

$\approx$ liver $>$ intestine $\approx$ gill $>$ spleen $>$ muscle. Similar patterns of metal accumulation have also been demonstrated for other aquatic animals (Kim et al. 2004). Metal accumulation in the organs of fish is dependent upon the exposure time and exposure dose as well as other factors, such as temperature, age, interaction with other metals, water chemistry, and metabolic activity of the fish (Campana et al. 2003). Here, $\mathrm{Cr}^{6+}$ accumulation in the mullet kidney was higher than that in the liver except at $400 \mu \mathrm{g} \mathrm{L}^{-1}$, indicating that $\mathrm{Cr}^{6+}$ accumulation in the kidney was more effective than that in the liver of the mullet. Similar results have been reported in the freshwater fish Cirrhinus mrigala, exposed to chromium (Palaniappan and Karthikeyan 2009); in catfish Ictalurus punctatus, exposed to mercuric chloride (Kendall 1977); and in carp (Cinier et al. 1999) and eel (Yang and Chen 1999) exposed to cadmium. Kraal et al. (1995) observed that the accumulation of metal in the kidney was higher than that in the liver during chronic cadmium exposure.
The main location of metal accumulation varies strongly across fish species. In addition, the maintenance of high accumulation in the intestine and kidney has often been observed, as these tissues comprise the principal route of excretion for most toxicants. In the present study, gill tissue contained a substantial amount of $\mathrm{Cr}^{6+}$ during the experimental period (Fig. 1). Demirak et al. (2006) and Malik et al. (2010) have indicated that the gills are highly $\mathrm{Cr}$-accumulating organs in fish due to their close relationship with the external environment. On the other hand, the concentrations of $\mathrm{Cr}^{6+}$ were lower in the muscles compared to the other organs examined in this study. This result is particularly important because the muscles contribute the greatest mass of the flesh that is consumed as food. Table 1 presents the AFs for various organs after $\mathrm{Cr}^{6+}$ exposure in the mullet. The AFs increased with exposure period and were inversely related to the exposure concentration in the organs of the mullet. The AFs were calculated for two major purposes: first, to measure 
Table 1 Accumulation factor (AF) over time in liver, kidney, spleen, intestine, gill, and muscle tissues of mullet, M. cephalus (mean \pm S.E.), exposed to the different concentrations

\begin{tabular}{|c|c|c|c|c|c|}
\hline \multirow[t]{2}{*}{ Tissue } & \multicolumn{5}{|c|}{ Hexavalent chromium $\left(\mu \mathrm{g} \mathrm{L}^{-1}\right)$} \\
\hline & 25 & 50 & 100 & 200 & 400 \\
\hline \multicolumn{6}{|l|}{2 weeks } \\
\hline Liver & $3.56 \pm 0.99$ & $2.88 \pm 0.49$ & $2.09 \pm .0 .54$ & $1.885 \pm 0.32$ & $1.58 \pm 0.25$ \\
\hline Kidney & $2.52 \pm 0.94$ & $3.80 \pm 0.12$ & $6.20 \pm 0.15$ & $6.22 \pm 0.02$ & $4.43 \pm 0.25$ \\
\hline Spleen & $0.08 \pm 0.01$ & $0.26 \pm 0.05$ & $0.01 \pm 0.06$ & $1.04 \pm 0.05$ & $0.98 \pm 0.05$ \\
\hline Intestine & $0.24 \pm 0.43$ & $0.44 \pm 0.30$ & $0.31 \pm 0.01$ & $0.45 \pm 0.02$ & $2.79 \pm 0.54$ \\
\hline Gill & $0.04 \pm 0.01$ & $0.08 \pm 0.05$ & $0.69 \pm 0.01$ & $2.03 \pm 0.07$ & $2.74 \pm 0.34$ \\
\hline Muscle & $0.31 \pm 0.03$ & $0.44 \pm 0.08$ & $0.39 \pm 0.19$ & $0.05 \pm 0.00$ & $0.39 \pm 0.04$ \\
\hline \multicolumn{6}{|l|}{4 weeks } \\
\hline Liver & $3.66 \pm 0.01$ & $4.30 \pm 0.29$ & $2.11 \pm 0.64$ & $2.47 \pm 0.13$ & $2.49 \pm 0.47$ \\
\hline Kidney & $2.57 \pm 0.02$ & $8.78 \pm 0.34$ & $8.68 \pm 0.93$ & $6.92 \pm 0.07$ & $4.44 \pm 0.41$ \\
\hline Spleen & $0.88 \pm 0.03$ & $5.58 \pm 0.01$ & $4.78 \pm 0.81$ & $4.35 \pm 0.15$ & $2.20 \pm 0.38$ \\
\hline Intestine & $0.72 \pm 0.09$ & $1.64 \pm 0.12$ & $1.69 \pm 0.51$ & $4.98 \pm 0.28$ & $3.74 \pm 0.85$ \\
\hline Gill & $0.58 \pm 0.19$ & $11.84 \pm 0.20$ & $6.96 \pm 0.51$ & $4.64 \pm 0.21$ & $3.90 \pm 0.56$ \\
\hline Muscle & $0.06 \pm 0.03$ & $1.88 \pm 0.03$ & $1.31 \pm 0.08$ & $0.49 \pm 0.03$ & $0.44 \pm 0.03$ \\
\hline
\end{tabular}

how much $\mathrm{Cr}^{6+}$ is accumulated with respect to aqueous exposure concentration, and second, to determine the finite limit in the ability of fish to accumulate metals (Sorensen 1991). Similar patterns have also been observed in carp (Cinier et al. 1999), eel (Yang and Chen 1999), and olive flounder after cadmium exposure (Kim et al. 2004).

\section{Metallothionein level and antioxidant enzyme activity}

The results of metallothionein (MT) in the mullet are presented in Fig. 2. The liver MT levels were significantly increased compared with the control with exposure period. However, the gill MT level did not show the significance from the control (Fig. 2). We observed that $\mathrm{Cr}^{6+}$ concentrations were the highest in the liver of the mullet, which was consistent with the findings of Çogun et al. (2006), who demonstrated that the liver is the main target for heavy metals. The high value of bioaccumulation observed in the liver reflects the affinity of the metal to these tissues. Because the liver is a major producer of metal-binding proteins, MT can be closely related to heavy metal exposure. In accordance with metal residues, Fig. 2 indicates that $\mathrm{Cr}^{6+}$ induces hepatic MT in the mullet. Hepatic MT synthesis is induced by cytokines and stress hormones and in fish by bivalent metals, including cadmium, zinc, copper, lead, and mercury. In mullet, $\mathrm{MT}$ is predominantly a $\mathrm{Cu}$-binding protein (Linde et al. 2005), which is similar to other conditions of hepatic $\mathrm{Cu}$ overload (Klein et al. 1997). In this study, the level of gill MT was not as high as that in the liver and did not significantly differ from the controls in the mullet (Fig. 2). In the rainbow trout O. mykiss, hepatic

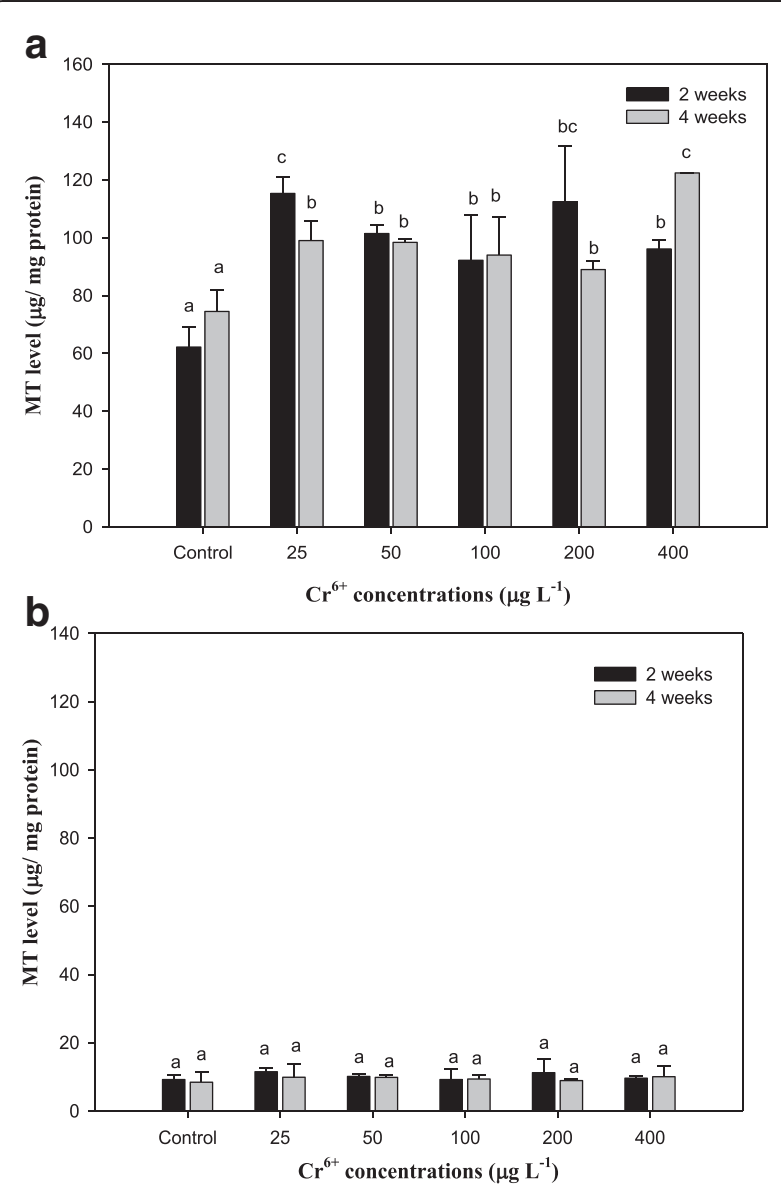

Fig. 2 Metallothionein (MT) in liver (a) and gill (b) tissues of mullet, M. cephalus, exposed to various $\mathrm{Cr}^{6+}$ concentrations for a 4-week time period 
and gill MT mRNA levels significantly increased over 7 days of $\mathrm{Cr}^{6+}$ exposure (Roberts and Oris 2004). These authors reported that although gill MT expression was not as high in the liver, expression occurred much earlier in the experiment (Roberts and Oris 2004). The gill, which lies in direct contact with the water column, would have greater interaction with $\mathrm{Cr}$ ions; however, in this study, the hepatic tissues exhibited a much greater capacity for production of MT than the gill. Furthermore, Roberts and Oris (2004) suggested that a greater amount of $\mathrm{Cr}^{3+}$ likely reaches the liver than the gill, thus inducing the liver to produce greater amounts of MT. MT has also been recognized as being involved in cellular antioxidant functions (Sato and Bremner 1993).

The capacity for $\mathrm{Cr}^{6+}$ conversion to $\mathrm{Cr}^{3+}$ in biological systems may be the mechanism of detoxification of $\mathrm{Cr}^{6+}$ (Lushchak et al. 2008). The results of reduced glutathione (GSH) in the mullet are reported in Fig. 3. As seen, the GSH level in the liver with $\mathrm{Cr}^{6+}$ exposure significantly increased. GSH is considered a first line of cellular defense against metals by chelating and detoxifying the metals, scavenging oxyradicals, and participating in

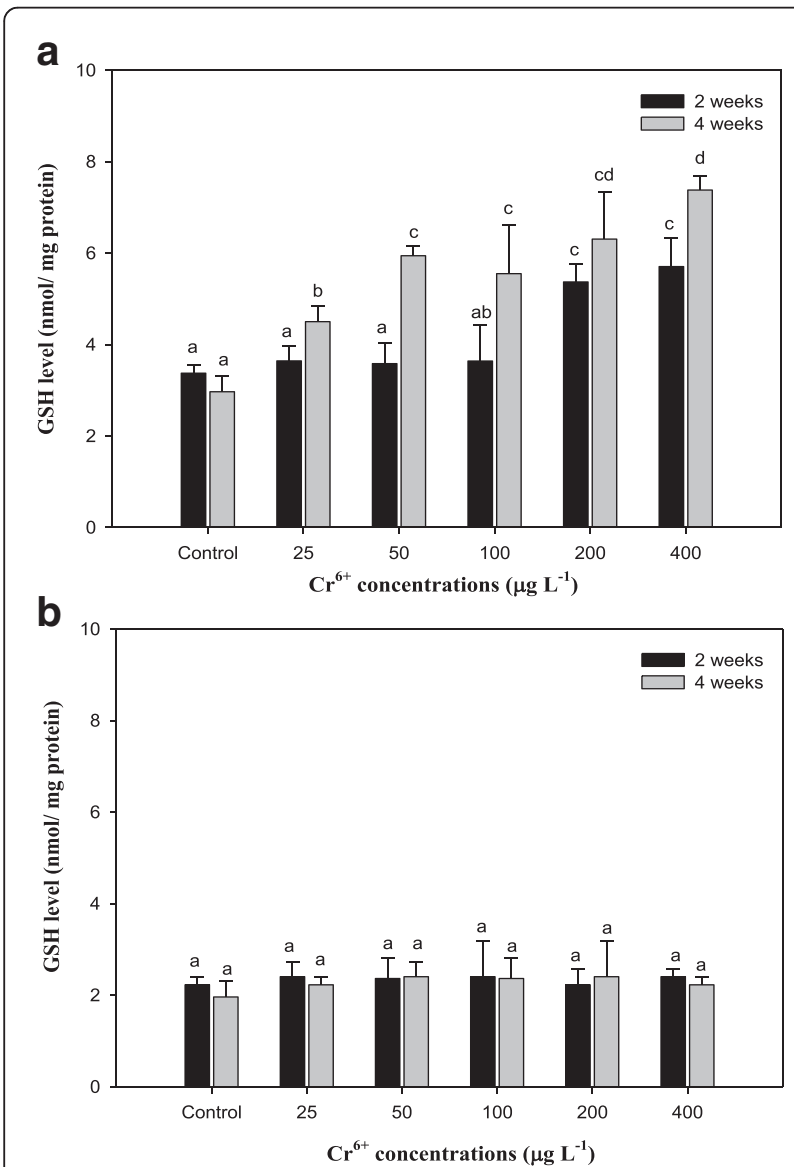

Fig. 3 Reduced glutathione (GSH) level in liver (a) and gill (b) tissues of mullet, M. cephalus, exposed to various $\mathrm{Cr}^{6+}$ concentrations for a 4-week time period detoxification reactions catalyzed by glutathione peroxidase (Thomas and Wofford 1984; Potter and Tran 1993; Sies 1999). Sengupta et al. (1990) showed that the acute oral administration of $\mathrm{Cr}$ to rats led to an increase of lipid peroxide and decreases in GSH, GST, and SOD of intestinal epithelial cells, whereas a chronic one led to increases in lipid peroxide, SOD, and GPx activity and to a decrease in GST activity. Exposure to heavy metals caused a time- and dose-dependent increase of GSH in various fish species, including mullet (Thomas and Wofford 1984; Lange et al. 2002; Zirong and Shijun 2007; Atli and Canli 2008). Atli and Canli (2008) concluded that the induction of GSH is probably due to the primary defense system for protecting the fish from oxidative stress. Similar results in this study indicated that exposure of the mullet to $\mathrm{Cr}^{6+}$ led to a significant increase in hepatic GSH levels, and these changes were associated with the exposure period and concentrations of $\mathrm{Cr}^{6+}$ (Fig. 3). However, we observed no changes in GSH in gill tissue. Kubrak et al. (2010) found that the gills of the goldfish Carassius auratus treated with $\mathrm{Cr}^{6+}$ did not result in any changes in GSH after $96 \mathrm{~h}$ and only the liver of goldfish $C$. auratus exhibited an increase in GSH. Consequently, we noted that GSH, including MT, in the mullet gill was not affected by $\mathrm{Cr}^{6+}$ treatment. It reflects the mullet liver has more responsibility for the detoxification of toxic effects of $\mathrm{Cr}^{6+}$ than the gills.

Glutathione $S$-transferase (GST) activities in the mullet liver and gills exposed to $\mathrm{Cr}^{6+}$ for 4 weeks were significantly reduced compared with those in the control as shown in Fig. 4. Similar results have been reported in previous studies addressing the effect of $\mathrm{Cr}$ on GST in goldfish C. auratus (Lushchak et al. 2009a, b; Kubrak et al. 2010). Elia et al. (2000) reported that high mercury concentrations induced a reduction of GST that was likely responsible for the increased hepatic GSH levels in catfish Ictalurus melas. GST is a well-known phase-II enzyme of the metabolism of detoxification, and it conjugates GSH to certain xenobiotic compounds or to their metabolites (Kim and Kang 2015). GST and GSH are important in protecting organisms from oxidative stress, and the fluctuation of GSH in organisms exposed to metals appears to be generally accompanied by variation in GST activity (Paris-Palacios et al. 2000).

Superoxide dismutase (SOD) activity in the mullet exposed to $\mathrm{Cr}^{6+}$ for 4 weeks is presented in Fig. 5. Significant changes were observed in the liver in only $400 \mu \mathrm{g} \mathrm{L}^{-1}$ at 2 weeks and 100-400 $\mu \mathrm{g} \mathrm{L}^{-1}$ at 4 weeks compared with the control. In the gills, SOD activity was significantly decreased in $400 \mu \mathrm{g} \mathrm{L}{ }^{-1}$ at 4 weeks. Wang et al. (2004) demonstrated that SOD completely abolished ROS generation induced by $\mathrm{Cr}^{6+}$. Roberts and Oris (2004) also suggested that the generation of ROS by the reduction of $\mathrm{Cr}^{6+}$ to $\mathrm{Cr}^{3+}$ occurred to a greater extent in the gill than the liver 

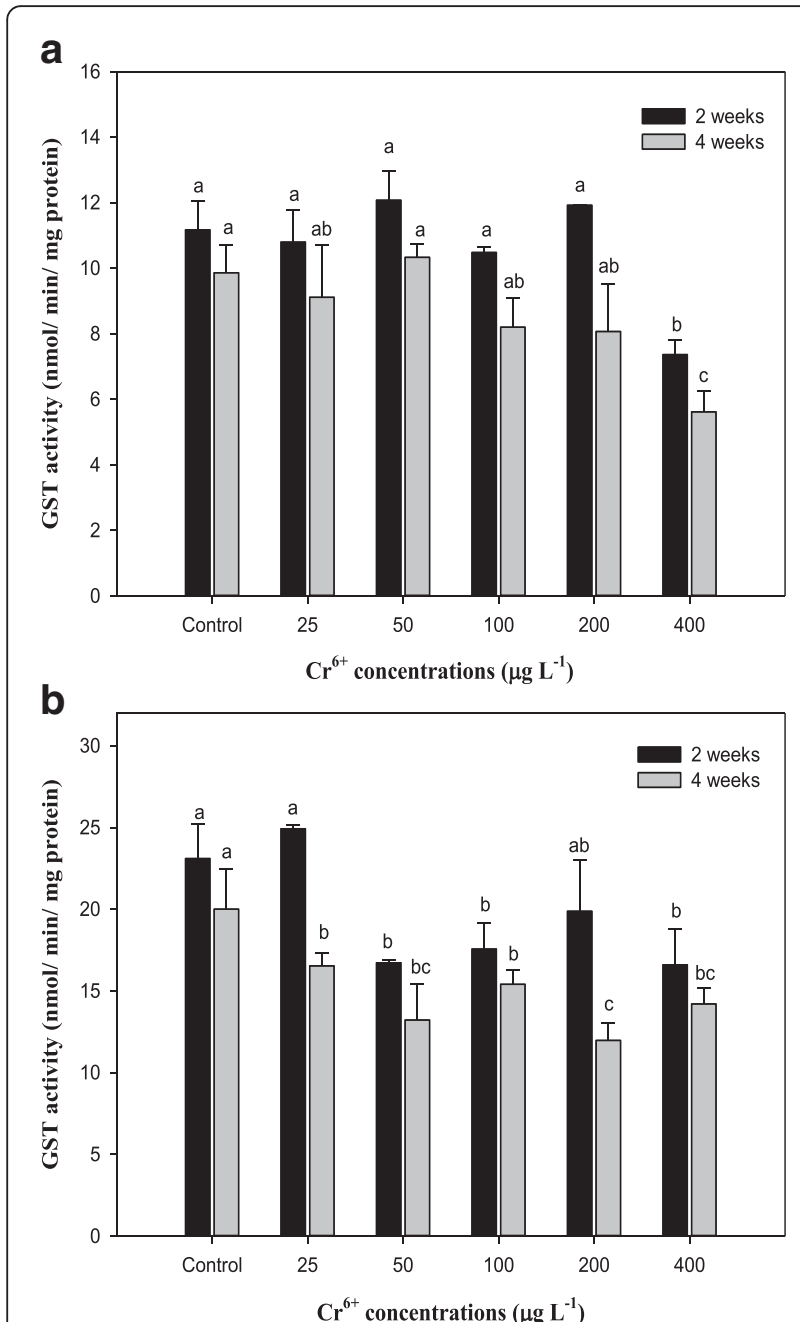

Fig. 4 Mean glutathione S-transferase (GST) activity in liver (a) and gill (b) tissues of mullet, M. cephalus, exposed to various $\mathrm{Cr}^{6+}$ concentrations for a 4-week time period

and that the gill was more sensitive than the liver to $\mathrm{Cr}$ toxicity. In this study, gill SOD activity in the mullet significantly increased at concentrations of $25-100 \mu \mathrm{g} \mathrm{L} \mathrm{L}^{-1}$; however, liver SOD activity was significantly reduced at 100-400 $\mu \mathrm{g} \mathrm{L}^{-1}$ (Fig. 5). Kubrak et al. (2010) reported that a 48-h exposure to $\mathrm{Cr}^{6+}$ reduced SOD activity in the brain of goldfish $C$. auratus and had no effect on liver SOD. Roberts and Oris (2004) demonstrated that SOD activity in rainbow trout, $O$. mykiss, significantly increased in the liver but did not change in the gill after $\mathrm{Cr}^{6+}$ exposure.

\section{Conclusions}

In conclusion, results from these studies indicate that a high concentration of $\mathrm{Cr}$-mediated oxidative stress could inactivate SOD, although $\mathrm{Cr}$ induces a tissue-specific antioxidant response. These results indicated that significant modulation of the activities of these biomarkers occurred in response to $\mathrm{Cr}^{6+}$ toxicity. This study highlighted
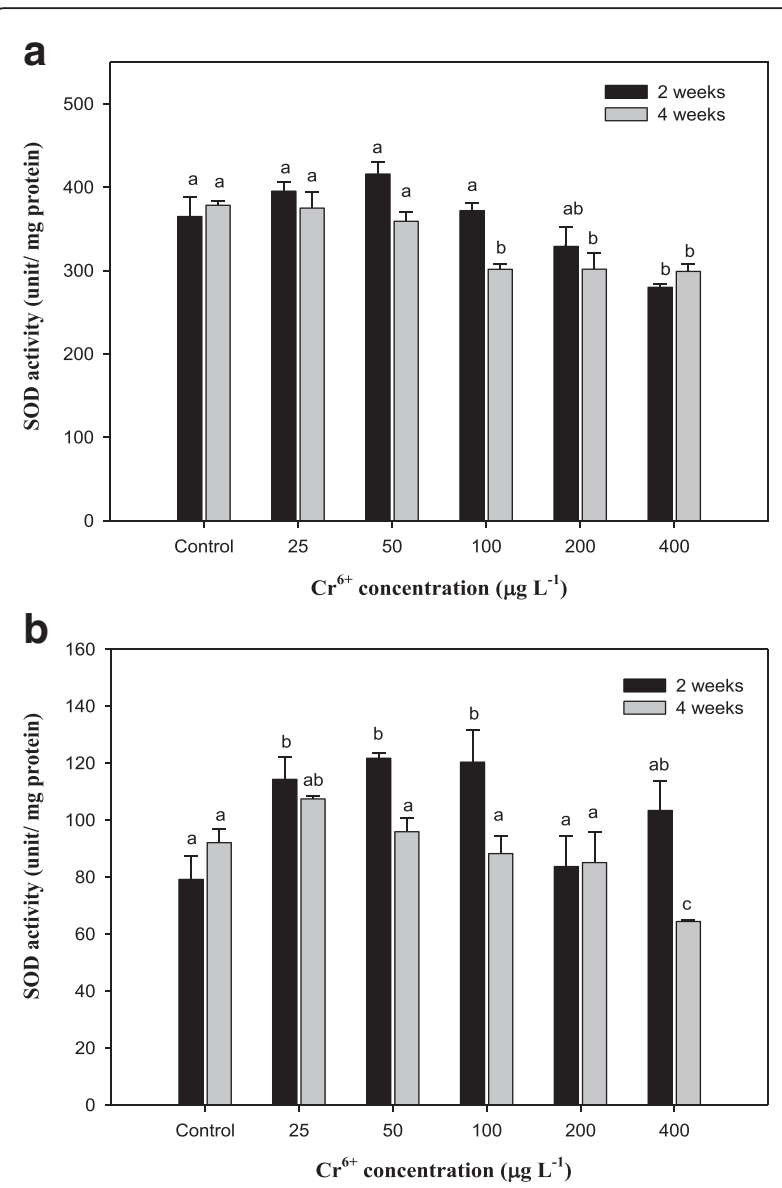

Fig. 5 Mean superoxide dismutase (SOD) units per milligram protein in liver (a) and gill (b) tissues of mullet, M. cephalus, exposed to various $\mathrm{Cr}^{6+}$ concentrations for a 4-week time period

that $\mathrm{Cr}^{6+}$ treatment at a level $\geq 200 \mu \mathrm{g} \mathrm{L}{ }^{-1}$ may affect bioaccumulation and that the AF increased with exposure time in the mullet. The responses of bioaccumulation, MT induction, and GSH to $\mathrm{Cr}^{6+}$ exposure were all very likely to be interconnected. Furthermore, this study demonstrated that $\mathrm{Cr}^{6+}$ exposure decreased the markers of oxidative stress, SOD and GST, in the mullet liver and gill.

\section{Acknowledgements}

This work was supported by a Research Grant of Pukyong National University (year 2015).

\section{Authors' contributions}

EYM carried out the experiments with TYA and wrote this article. TYA carried out the experiments. J-CK helped make the design of this experiment and helped write this article. All authors read and approved the final manuscript.

\section{Competing interests}

The authors declare that they have no competing interests.

\section{Author details}

${ }^{1}$ Institute of Fisheries Sciences, Pukyong National University, Busan, South Korea. ${ }^{2}$ Department of Aquatic Life Medicine, Pukyong National University, Busan 608-737, South Korea. 
Received: 23 May 2016 Accepted: 28 May 2016

Published online: 16 June 2016

\section{References}

Amiard JC, Amiard-Triquet C, Barka S, Pellerin J, Rainbow PS. Metallothioneins in aquatic invertebrates: their role in metal detoxification and their use as biomarkers. Aquat Toxicol. 2006;76(2):160-202.

Anosike EO, Uwakwe AA, Monanu MO, Ekeke Gl. Studies on human erythrocytes glutathione-S transferase form $\mathrm{HbAA}, \mathrm{HbAS}$ and hbSS subject. Biochem Biomed Acta. 1991;50:1051-5.

Arillo A, Melodia F. Effect of hexavalent chromium on trout mitochondria. Toxicol Lett. 1998:44:71-6.

Atli G, Canli M. Response of metallothionein and reduced glutathione in a freshwater fish Oreochromis niloticus following metal exposures. Environ Toxicol Pharmacol. 2008;25:33-8.

Bradford MM. A rapid and sensitive method for the quantitation of microgram quantities of protein utilizing the principle of protein-dye binding. Anal Biochem. 1976;72:248-54

Campana O, Saraquete C, Blasco J. Effect of lead on ALA-D activity, metallothionein levels, and lipid peroxidation in blood, kidney, and liver of the toadfish Halobatrachus didactylus. Ecotoxicol Environ Safe. 2003;55:116-25.

Cinier CC, Petit-Ramel M, Faure R, Garin D, Bouvet Y. Kinetics of cadmium accumulation and elimination in carp Cyprinus carpio tissues. Comp Biochem Physiol. 1999;122C:345-52.

Çogun HY, Yuzereroglu TA, Firat O, Gok G, Kargin F. Metal concentrations in fish species form the Northeast Mediterranean Sea. Environ Monit Assess. 2006;121:431-8.

Demirak A, Yilmaz F, Tuna AL, Ozdemir N. Heavy metals in water, sediment and tissues of Leuciscus cephalus from a stream in southwestern Turkey. Chemosphere. 2006;63:1451-8.

DeForest DK, Brix KV, Adams WJ. Assessing metal bioaccumulation in aquatic environments: The inverse relationship between bioaccumulation factors, trophic transfer factors and exposure concentration. Aquat Toxicol. 2007;84: 236-246.

Elia AC, Dörr AJM, Mantilacci L, Taticchi MI, Galarini R. Effects of mercury on glutathione and glutathione-dependent enzymes in catfish (Ictalurus melas $\mathrm{R}$. ). In: Markert B, Friese $\mathrm{K}$, editors. Trace elements - their distribution and effects in the environment: trace metals in the environment. Vol. 4. Amsterdam, Netherlands: Elsevier Science; 2000. p. 411-21.

Habig WH, Pabst MJ, Jakoby WB. Glutathione S-transferase: the first enzymatic step in mercapturic acid formation. J Biol Chem. 1974;249(22):7130-9.

Holwerda DA. Cadmium kinetics in freshwater clams. V. Cadmium-copper interaction in metal accumulation by Anodonta cyngnea and characterization of metal binding protein. Arch Environ Contam Toxicol. 1991;21:432-7.

Kendall MW. Acute effects of methyl mercury toxicity in channel catfish (Ictalurus punctatus) liver. Bull Environ Contam Toxicol. 1977;18(2):143-51.

Kim JH, Kang JC. Oxidative stress, neurotoxicity, and non-specific immune responses in juvenile red sea bream, Pagrus major, exposed to differnet waterborne selenium concentrations. Chemosphere. 2015;135:46-52.

Kim SG, Jee JH, Kang JC. Cadmium accumulation and elimination in tissues of juvenile olive flounder, Paralichthys olivaceus after sub-chronic cadmium exposure. Environ Poll. 2004;127:117-23.

Klein D, Michaelsen S, Sato S, Luz A, Stampfl A, Summer KH. Binding of Cu to metallothionein in tissues of the LEC rat with inherited abnormal copper accumulation. Arch Toxicol. 1997;71:340-3.

Kraal MH, Kraak MHS, De Groot CJ, Davids C. Uptake and tissue distribution of dietary and aqueous cadmium by carp (Cyprinus carpio). Ecotoxicol Environ Saf. 1995;31:179-83.

Kubrak OI, Lushchak OV, Lushchak JV, Torous IM, Storey JM, Storey KB, et al. Chromium effects on free radical processes in goldfish tissues: comparison of $\mathrm{Cr}(\mathrm{III})$ and $\mathrm{Cr}(\mathrm{VI})$ exposure on oxidative stress markers, glutathione status and antioxidant enzymes. Comp Biochem Physiol. 2010;152(C):360-70.

Lange A, Ausseil O, Segener $\mathrm{H}$. Alterations of tissue glutathione levels and metallothionein mRNA rainbow trout during single and combined exposure to cadmium and zinc. Comp Biochem Physiol. 2002;131C:231-43.

Linde AR, Klein D, Summer KH. Phenomenon of hepatic overload of copper in Mugil cephalus: role of metallothionein and patterns of copper cellular distribution. Basic Clinical Pharma Toxicol. 2005:97:230-5.

Lushchak OV, Kubrak OI, Nykorak MZ, Storey KB, Lushchak VI. The effect of potassium dichromate on free radical processes in goldfish: possible protective role of glutathione. Aquat Toxicol. 2008;87:108-14.
Lushchak OV, Kubrak OI, Lozinsky OV, Storey JM, Storey KB, Lushchak VI. Chromium (III) induces oxidative stress in goldfish liver and kidney. Aquat Toxicol. 2009;92:45-52.

Lushchak OV, Kubrak OI, Torous IM, Nazarchuk TY, Storey KB, Lushchak VI. Trivalent chromium induces oxidative stress in goldfish brain. Chemosphere. 2009;75:56-62

Malik N, Biswas AK, Qureshi TA, Borana K, Virha R. Bioaccumulation of heavy metals in fish tissues of a freshwater lake of Bhopal. Environ Monit Assess. 2010;160:267-76

Palaniappan PR, Karthikeyan S. Bioaccumulation and depuration of chromium in the selected organs and whole body tissues of freshwater fish Cirrhinus mrigala individually and in binary solutions with nickel. J Environ Sci. 2009;21:229-36.

Paris-Palacios S, Biagianti-Risbourg S, Vernt G. Biochemical and (ultra) structural hepatic perturbations of Brachydanio reio (Teleostei, Cyprinidae) exposed to two sublethal concentrations of copper sulfate. Aquat Toxicol. 2000:50:109-24.

Potter DW, Tran TB. Apparent rates of glutathione turnover in rat tissues. Toxicol Appl Pharmacol. 1993;120:186-92.

Roberts AP, Oris JT. Multiple biomarker response in rainbow trout during exposure to hexavalent chromium. Comp Biochem Physiol. 2004;138C:221-8.

Sato M, Bremner I. Oxygen free radicals and metallothionein. Free Radic Biol Med. 1993;14:325-37.

Schlenk D, Rice CD. Effect of zinc and cadmium treatment on hydrogen peroxide-induced mortality and expression of glutathione and metallothionein in teleost hepatoma cell line. Aquat Toxicol. 1998:43:121-9.

Sengupta T, Chattopadhyay D, Ghosh N, Das M, Chatterjee GC. Effect of chromium administration on glutathione cycle of rat intestinal epithelial cells. Indian J Exp Biol. 1990;28:1132-5.

Sies H. Glutathione and its role in cellular functions. Free Radic Biol Med. 1999;27:916-21.

Sorensen EM. Cadmim. In: Metal poisoning in fish. Boca Raton: CRC Press; 1991. p. 175-234.

Srivastava SK, Beutler E. Glutathione metabolism of the erythrocyte. Biochem J. 1970;119:353-7.

Thomas P, Wofford HW. Effects of metals and organic compounds on hepatic glutathione, cysteine, and acid-soluble thiol levels in mullet (Mugil cephalus L. ). Toxicol Appl Pharmacol. 1984;76(1):172-82.

Viarengo A, Nott JA. Mechanisms of heavy metal cation homeostasis in marine invertebrates. Comp Biochem Physiol. 1993;104C:355-72.

Wang S, Leonard SS, Ye J, Gao N, Wang N, Shi X. Role of reactive oxygen species and $\mathrm{Cr}(\mathrm{VI})$ in Ras-mediated signal transduction. Mol Cell Biochem. 2004;255:119-27.

Yang HN, Chen HC. Uptake and elimination of cadmium by Japanese eel, Anguilla japonica, at various temperatures. Bull Environ Contam Toxicol. 1999:56:670-6.

Zirong X, Shijun B. Effects of waterborne Cd exposure on glutathione metabolism in Nile tilapia (Oreochromis niloticus) liver. Ecotoxicol Environ Safe. 2007;67:89-94.

\section{Submit your next manuscript to BioMed Central and we will help you at every step:}

- We accept pre-submission inquiries

- Our selector tool helps you to find the most relevant journal

- We provide round the clock customer support

- Convenient online submission

- Thorough peer review

- Inclusion in PubMed and all major indexing services

- Maximum visibility for your research

Submit your manuscript at www.biomedcentral.com/submit

) Biomed Central 